\title{
Effect of Artemisia Absinthium and Malva Sylvestris on Antioxidant Parameters and Abomasal Histopathology in Lambs Experimentally Infected with Haemonchus Contortus
}

\section{Dominika Mravcakova ( $\nabla$ mravcakova@saske.sk)}

Institute of Animal Physiology, Centre of Biosciences of Slovak Academy of Sciences

https://orcid.org/0000-0002-9070-0558

Małgorzata Sobczak-Filipiak

Warsaw University of Life Sciences, Institue of Veterinary Medicine

\section{Zora Váradyová}

Institute of Animal Physiology, Centre of Biosciences of Slovak Academy of Sciences

\section{Katarína Kucková}

Institute of Animal Physiology, Centre of Biosciences of Slovak Academy of Sciences

\section{Klaudia Cobanova}

Institute of Animal Physiology, Centre of Biosciences of Slovak Academy of Sciences

\section{Peter Maršík}

Institute of Experimental Botany Czech Academy of Sciences: Ustav Experimentalni Botaniky Akademie ved Ceske republiky

\section{Jan Tauchen}

Czech University of Life Sciences Prague: Ceska Zemedelska Univerzita v Praze

\section{Jaroslav Vadlejch}

Czech University of Life Sciences Prague: Ceska Zemedelska Univerzita v Praze

\section{Marcin Mickiewicz}

Warsaw University of Life Sciences: Szkola Glowna Gospodarstwa Wiejskiego w Warszawie Jaroslaw Kaba

Warsaw University of Life Sciences: Szkola Glowna Gospodarstwa Wiejskiego w Warszawie Marian Varady

Institute of Parasitology of the Slovak Academy of Sciences: Parazitologicky ustav Slovenskej akademie vied

\section{Research article}

Keywords: Abomasum, Antioxidant parameters, Gastrointestinal nematode parasite, Histopathological changes, Local immune response, Sheep 
Posted Date: October 13th, 2020

DOl: https://doi.org/10.21203/rs.3.rs-88899/v1

License: (c) (i) This work is licensed under a Creative Commons Attribution 4.0 International License. Read Full License 


\section{Abstract}

Background: Haemonchus contortus is a blood-feeding gastrointestinal nematode (GIN) that parasitizes in the abomasum of ruminants. Infections caused by this nematode possess a serious threat to livestock production worldwide. The influence of medicinal plants using for control of haemonchosis on the local immune response of abomasal mucosae in GIN-infected sheep, however, has not been reported. This study evaluated the effect of Artemisia absinthium and Malva sylvestris as dietary supplements containing bioactive compounds on antioxidant response and histopathological changes in the abomasa of the lambs. Twenty-four lambs were divided into four groups: unsupplemented lambs (UNS), lambs supplemented with $A$. absinthium (ART), lambs supplemented with $M$. sylvestris (MAL), and lambs supplemented with both plants (ARTMAL). All lambs were infected orally with approximately 5000 L3 larvae of $H$. contortus. The experiment was conducted for $75 \mathrm{~d}$, all animals were then slaughtered, and the abomasal tissues were examined for antioxidant parameters and histopathology.

Results: Methanolic extracts of wormwood and mallow were separated into four fractions by semipreparative high-performance liquid chromatography, which identified saccharides, phenols, phenolic acids, flavonoids, polyphenols, esters, fatty acids, lipids, and other substances. The concentration of malondialdehyde in the abomasal mucosa was lower in ARTMAL $(P<0.05)$, and the total antioxidant capacity was higher in MAL $(P<0.05)$, than in UNS. Serum antioxidant parameters were not affected by the treatments $(P>0.05)$. Histopathological changes were mainly detected in the mucosal membrane of the abomasum, with the presence of infiltrates of inflammatory cells in MAL, ART, and ARTMAL. Increase mucus production was observed in the ARTMAL. The number of mast cells was significantly higher in UNS and ART than MAL $(P<0.01$ and $P<0.05)$. Plasma cell numbers were higher in ARTMAL than MAL $(P<0.05)$. Abomasal tissue regenerated more frequently in ARTMAL than the other experimental groups.

Conclusions: These results represent the first report of the impact of $A$. absinthium and $M$. sy/vestris on antioxidant parameters and local immune responses of abomasal mucosa of lambs infected with a GIN parasite. Wormwood and mallow applied as dietary supplements may increase the resistance of lambs to GIN infections.

\section{Background}

Gastrointestinal nematodes (GINs) represent a major threat to the small-ruminant industry worldwide. Haemonchus contortus is one of the most pathogenic GINs, mainly because of its blood-feeding behaviour. Infections with this parasite are associated with negative impacts on animal health, welfare, and production, which can lead to increased mortality, predominantly in young animals (1). The control of GIN infections is usually limited to the frequent and repeated use of anthelmintic drugs. Their excessive use, however, has led to the development of anthelmintic resistance in GIN populations (2) and has increased the level of chemical residues in animal products (3). The expansion of anthelmintic resistance and consumer demand for chemically free animal products have created an urgent need for a more 
sustainable alternative control of $\operatorname{GINs}(4,5)$, such as nutritional supplementation with medicinal plants (6-8).

Medicinal plants contain various bioactive compounds, such as alkaloids, flavonoids, terpenoids, lactones, and glycosides, that have different modes of therapeutic action, e.g. immunomodulatory, antiinflammatory, antioxidant, or anthelmintic (9-12). Some secondary metabolites of plants have direct anthelmintic activity against GINs (13-15). Our previous studies, however, concluded that supplementation with a mixture of dried medicinal plants in the diet of lambs could slow the dynamics of infection and increase the resistance of lambs to parasitic infection (16-18).

The supplementation of diets with plant nutraceuticals containing bioactive substances has received increasing attention for manipulating host nutrition and indirectly improving animal resistance to GIN infections (19-21). Nutraceuticals can provide enough nutrients essential for tissue maintenance and blood homeostasis, but also for host immune responses against parasites (7), which can affect the overall health of animals. Immunity to nematodes is associated with innate and acquired responses, but the local cellular immune responses in host abomasa are considered the most important defences against haemonchosis. Mucosal mast-cell hyperplasia, the formation of globular leukocytes, eosinophilia (an increase in eosinophils in blood and tissue), increased mucus production in the abomasum, and the production of specific antibodies typically emerge during infection (22-24). The presence of nematodes in the abomasum can also induce the production of reactive oxygen species by immune cells, which can damage the parasites and cause oxidative stress in the host (25). Plant secondary metabolites may improve the health of animals through their antioxidant and immune-enhancing properties $(26,27)$. The mechanisms of sheep resistance to GINs via plant secondary metabolites, however, are not fully understood.

Many studies have investigated alterations in sheep abomasa in association with $H$. contortus infection $(28-30)$. To our knowledge, the influence of medicinal plants on antioxidant parameters and histopathological changes in sheep abomasa have not been reported. We hypothesised that dietary supplementation with medicinal plants would influence the local immune response in the abomasum and positively affect the antioxidant status of infected animals. This study aimed to evaluate the effect of diets containing medicinal wormwood and mallow (1) on antioxidant parameters in sera and abomasal mucosa, and (2) on histopathological changes in the abomasal tissues of lambs experimentally infected with $H$. contortus.

\section{Results}

\section{Plant methanolic extracts}

The methanolic extracts of wormwood, Artemisia absinthium, and mallow, Malva sylvestris, were each divided into four fractions (Table 1). The fractions of the $A$. absinthium methanolic extract contained the highest concentrations of very polar substances, saccharides, peptides, and polar phenolic acids (46 
$000 \mu \mathrm{g} / \mathrm{mL})$, followed by polyphenols, less polar phenolic acids, and sesquiterpenes $(20000 \mu \mathrm{g} / \mathrm{mL})$. Nonpolar substances, lipids, resins, and di- and triterpenes had concentrations of $12000 \mu \mathrm{g} / \mathrm{mL}$, and lowpolarity polyphenols, phenolic acids, and sesquiterpenes had concentrations of $6000 \mu \mathrm{g} / \mathrm{mL}$. The fractions of the M. sy/vestris methanolic extract contained $150000 \mu \mathrm{g} / \mathrm{mL}$ saccharides and polar phenols, $42000 \mu \mathrm{g} / \mathrm{mL}$ anthocyanins and other phenolic compounds, $18000 \mu \mathrm{g} / \mathrm{mL}$ nonpolar substances, esters, fatty acids, and lipids, and $9000 \mu \mathrm{g} / \mathrm{mL}$ polyphenols, flavonoids, and phenolic acids.

Table 1

Composition and concentration of the fractions of plant methanolic extracts.

\begin{tabular}{|c|c|c|c|c|}
\hline $\begin{array}{l}\text { Fraction } \\
(\mathrm{F})\end{array}$ & $\begin{array}{l}\mathrm{RT} \\
(\mathrm{min})\end{array}$ & $\begin{array}{l}\text { Composition of } \\
\text { fraction }\end{array}$ & & $\begin{array}{l}\text { Concentration } \\
(\mu \mathrm{g} / \mathrm{mL})\end{array}$ \\
\hline \multicolumn{5}{|c|}{ A. absinthium } \\
\hline F1 & $\begin{array}{l}1.00- \\
5.25\end{array}$ & $\begin{array}{l}\text { Very polar substances, sugars, polar peptides and } \\
\text { proteins, polar phenolic acids }\end{array}$ & 45.913 & 46000 \\
\hline $\mathrm{F} 2$ & $\begin{array}{l}5.25- \\
18.00\end{array}$ & $\begin{array}{l}\text { Polyphenols, less polar phenolic acids, } \\
\text { sesquiterpenes }\end{array}$ & 19.813 & 20000 \\
\hline F3 & $\begin{array}{l}18.00- \\
25.00\end{array}$ & $\begin{array}{l}\text { A similar spectrum of substances as } \mathrm{F} 2 \text {, but of } \\
\text { lower polarity }\end{array}$ & 5.583 & 6000 \\
\hline $\mathrm{F} 4$ & $\begin{array}{l}25.00- \\
45.00\end{array}$ & $\begin{array}{l}\text { Nonpolar substances, lipids, resins, di- and } \\
\text { triterpenes }\end{array}$ & 12.102 & 12000 \\
\hline \multicolumn{5}{|c|}{ M. sylvestris } \\
\hline $\mathrm{F} 1$ & $\begin{array}{l}1.00- \\
5.25\end{array}$ & Sugars, polar phenols & 150.441 & 150000 \\
\hline $\mathrm{F} 2$ & $\begin{array}{l}5.25- \\
10.50\end{array}$ & Anthocyanins, other phenolic compounds & 41.818 & 42000 \\
\hline F3 & $\begin{array}{l}10.50- \\
17.60\end{array}$ & Polyphenols, flavonoids, phenolic acids & 9.403 & 9000 \\
\hline F4 & $\begin{array}{l}17.60- \\
45.00\end{array}$ & Nonpolar substances, esters, fatty acids, lipids & 18.368 & 18000 \\
\hline
\end{tabular}

\section{Antioxidant Parameters}

The folds of the abomasa were flushed with saline, and the mucosae were subsequently sampled by scraping the inside surfaces with a glass slide and stored at $-80^{\circ} \mathrm{C}$ until analysis. Tissue processing and antioxidant assays have been previously described in more detail (51). The activity of glutathione peroxidase (GPx) in the serum and abomasal mucosa was determined spectrophotometrically as described by (52). One unit of enzymatic activity was equal to $1 \mu \mathrm{mol}$ of NADPH oxidised per minute at $340 \mathrm{~nm}$ and is expressed per gramme of tissue protein or millilitre of serum. The total antioxidant 
capacity (TAC) of the serum and abomasal mucosa was determined using a ferric reducing antioxidant power assay following the method of (53). The final results are expressed in $\mathrm{mmol} \mathrm{Fe} \mathrm{F}^{2+} / \mathrm{L}$ of serum or $\mu \mathrm{mol} \mathrm{Fe}{ }^{2+} / \mathrm{g}$ of tissue protein. The malondialdehyde (MDA) concentration in the serum and tissue homogenate was measured using a modified fluorometric method as described by (54). Protein concentrations in the tissues were determined spectrophotometrically as described by (55).

\section{Abomasum Histology}

Each abomasum was removed after necropsy, opened along the greater curvature, and gently washed with water to recover nematodes. Two tissue samples from fundic part of the abomasum (approximately $3 \times 3 \mathrm{~cm}$ ) were removed and routinely fixed in $10 \%$ neutral buffered formalin, embedded in paraffin (Paraplast, Sigma-Aldrich, Steinheim, Germany), and subsequently cut with a rotatory microtome into sections $4 \mu \mathrm{m}$ thick. The paraffin slides were automatically stained with haematoxylin and eosin (Varistain Gemini Thermo Scientific, Leicestershire, UK) for histopathological examination and counting eosinophils, plasma cells, and mitotic figures (to determine mitotic activity of the epithelial cells at the neck of glands). Mucus was stained with Periodic acid-Shiff stain, and mast cells were stained with toluidine blue. Eosinophils, plasma cells, mast cells, and mitotic figures in the epithelial cells of the glands in abomasal mucous membrane were counted for each animal in 10 randomly selected fields at an objective magnification of $400 \times$ using an Olympus BX43 light microscope equipped with an SC30 digital camera (Olympus Optical, Tokyo, Japan). Photomicrographs were recorded and analysed using CellSens Entry 2011 (Olympus Lifescience, Tokyo, Japan).

\section{Immune Cells In The Abomasal Mucosa}

Figure 2 shows the mean numbers of eosinophils (A), mast cells (B), plasma cells (C), and mitotic figures (D) on day 75 in the abomasal mucosae of the lambs in all experimental groups. The number of eosinophils in the abomasal mucosa did not differ significantly between the groups (Fig. 2A). The number of mast cells was significantly higher in UNS and ART $(P<0.01$ and 0.05 , respectively) than MAL (Fig. 2B). The mean number of plasma cells was significantly higher $(P<0.05)$ in ARTMAL than MAL (Fig. 2C). The number of mitotic figures (mitotic activity of the epithelial cells at the neck of glands; Fig. 1F) was significantly higher in ARTMAL than MAL $(P<0.05)$ and UNS and ART $(P<0.001)$. Mitosis was more frequent in MAL $(P<0.05)$ than UNS and ART (Fig. 2D).

\section{Discussion}

This experiment was part of a study investigating the anthelmintic activity of $A$. absinthium and $M$. sylvestris against $H$. contortus in lambs (31). The present part of the study investigated the indirect increase in resistance of lambs infected with $H$. contortus by supplementing their diets with $A$. absinthium and M. sylvestris. The fractionation of the methanolic extracts indicated that $M$. sy/vestris 
contained more saccharides, polar phenols, and a higher concentration of flavonoids than $\operatorname{did} A$. absinthium. M. sylvestris flowers are rich in bioactive compounds, such as phenols, flavonoids, and carotenoids, which are characterised by their powerful antioxidant properties (32). In contrast, $A$. absinthium stems contained proteins, sesquiterpenes, di- and triterpenes, and resins but lower concentrations of phenolic acids and polyphenols. A. absinthium, however, also contains many phytochemical compounds such as lactones, terpenoids, essential oils, resins, tannins, and phenols that have antioxidant, antimicrobial, anthelmintic, and immunomodulatory activity (33).

The presence of nematodes in sheep abomasa is usually associated with the production of reactive oxygen species by immune cells, which can represent host defensive mechanisms against parasites but can also generate oxidative stress (34). Oxidative stress arises as an imbalance between the formation of oxidants and antioxidants in the body and can damage lipids, DNA, proteins, and carbohydrates, which eventually lead to tissue damage and inflammation (25). Traditional medicinal plants have long been known for their antioxidant properties. Amongst all secondary metabolites in plants, phenolic compounds, which are present in both $A$. absinthium and M. sylvestris (31), are considered to be the strongest natural antioxidants (35). The analysis of the antioxidant parameters indicated that dietary supplementation with two medicinal plants in ARTMAL reduced the MDA level in the abomasa of infected sheep by day 75 , which could indicate the inhibition of lipid peroxidation and the reduction of oxidative stress in abomasal tissue. MDA levels tend to increase during parasitic infection, due to cellular injury in tissues and are an indicator of oxidative stress (36). The antioxidant activity of $A$. absinthium has been previously reported (33) and has been attributed to an abundant phenolic content. Bora and Sharma (37) reported that $A$. absinthium had strong antioxidant properties and could be used to prevent oxidative stress during disease by reducing lipid peroxidation. M. sylvestris also has strong antioxidant properties represented by the reduction of reactive oxygen species and inhibition of lipid peroxidation (32). MDA levels in our study were significantly lower only in ARTMAL compared to UNS, so the combination of these two herbs may be necessary to reduce oxidative stress. Interestingly, TAC in the abomasum was significantly higher only in MAL. This parameter represents all antioxidants present in tissue or plasma and provides an integrated parameter of the status of antioxidants. Our results indicated that supplementing diets with these medicinal plants could reduce oxidative stress and affect the antioxidant status of lambs infected with $H$. contortus. The parameters of serum antioxidants, however, were not affected by the treatments, so we suggest that these two medicinal plants only affect antioxidant parameters locally.

Protective immune responses against $H$. contortus are associated with the infiltration of inflammatory cells, such as lymphocytes, macrophages, eosinophils, mast cells, and plasma cells, into the abomasal mucosa (24). Our study found similar infiltrations with immune cells in all groups, with the highest intensity in ARTMAL and lowest in UNS. Paolini et al. (38) also observed a higher number of inflammatory cells in the fundic part of the abomasa of goats infected with $\mathrm{H}$. contortus that received tannins representing $5 \%$ of the dietary dry matter compared to a control group. The inflammatory infiltrates in our experiment were mainly localised in both the superficial and basal portions of the mucosa in all treated groups but only in the basal portions of the abomasal glands in UNS. Pérez et al. 
(39) found infiltrates of eosinophils and mononuclear cells mostly in the deep areas of the mucosa in goats infected with $\mathrm{H}$. contortus, with fewer infiltrates in the submucosa. The expansion of immune cells to all layers of the mucosa in our study was probably affected by the stronger inflammation in these groups or by the immunomodulatory effect of the plant supplements. Five of the six animals in MAL were characterised by the presence of lymphoid nodules in the mucosa. Gossner et al. (40) frequently detected these lymphoid aggregates in susceptible lambs infected with the abomasal nematode Teladorsagia circumcincta. Salman and Duncan (41) also observed lymphoid aggregates at the base of the mucosa in sheep vaccinated against $H$. contortus, which was due to repeated immunisation and an improved immune response. In the present study the nutrient supplementation with plants and their bioactive compounds probably affected local immune response in the abomasum.

The gastrointestinal tract is covered with a protective layer of mucus containing mainly mucins and other substances such as immunoglobulins, which can inhibit the growth of parasites or eliminate them from the tissue. This mucosal layer represents the first line of innate defence against GIN infections (42). Increased secretion of mucus and the occurrence of inhibitory substances in the mucus have been associated with the development of immunity against GINs (43). Pérez et al. (39) described an increase in mucus secretion in the abomasum together with the infiltration of immune cells into the abomasal mucosa of goats infected with $\mathrm{H}$. contortus. Mucus in our experiment was produced most strongly throughout the thickness of the mucosa in ARTMAL, perhaps due to the bioactive compounds of the plants and the strongest intensity of inflammation in this group. ARTMAL also had the lowest worm count in the abomasa (31), which could have been caused by the elimination of parasites by the mucus.

The infiltration of abomasal tissue by eosinophils, mast cells, and other immune cells is a natural response to $H$. contortus infection in small ruminants. Eosinophilia is often associated with resistance (44) because eosinophils play an essential role in the host response against GINs by killing the parasites. The number of tissue eosinophils did not differ significantly between the experimental groups, perhaps because medicinal plants do not affect counts of tissue eosinophils. Paolini et al. (38) reported similar results, where dietary supplementation with condensed tannins did not affect the numbers of eosinophils in the abomasa of goats infected with $H$. contortus. The lack of significant differences between the experimental groups may also have been due to an inappropriately timed necropsy. Terefe et al. (45) reported no significant differences in the number of tissue eosinophils between susceptible and resistant breeds of lambs infected with $H$. contortus. They also suggested an inappropriate timing of necropsy, which was supported by the results of a haematological examination, where blood eosinophilia peaked between 10 and $20 \mathrm{~d}$ after infection. We did not analyse blood parameters, so we could not confirm this finding. Our previous studies, however, did not identify any changes in counts of blood eosinophils in groups treated with a mixture of medicinal plants $(16,17)$, so we did not expect medicinal plants to positively affect counts of blood and tissue eosinophils.

Mast cells are involved in a variety of physiological functions, including parasite elimination (46). Their expansion and distribution in tissues can change in response to helminth parasites (47). The numbers of mucosal mast cells in our experiment were higher in ART and ARTMAL than MAL. Medicinal plants are a 
source of bioactive compounds, which can influence the natural immunity of an animal. For example, Tzamaloukas et al. (48) found that the local immune response against $T$. circumcincta improved in lambs that grazed on chicory and sulla. These lambs had higher numbers of mast cells and globular leucocytes in abomasal mucosa and a poorer development of nematodes. In our study, the lowest number of mast cells in the group treated with $M$. sylvestris may have been due to the anti-inflammatory properties of the bioactive compounds in this plant (32). These anti-inflammatory properties may help to account for the higher number of mast cells in UNS than MAL. H. contortus infections are associated with an increase in plasma cells in abomasal tissue (49), and the presence of these cells has been linked to the production of nematode-specific antibodies, which play a role in protective immune responses (24). MAL in our experiment had fewer plasma cells than did ARTMAL. Again, the anti-inflammatory effect of the $M$. sylvestris bioactive compounds may have affected the reduction of plasma cells in the abomasal tissue. Interestingly, the levels of IgG and IgA in the serum did not differ significantly between MAL and ARTMAL (31), but we assume that the difference in antibody production could be local, in the abomasal mucus. Analysing local antibody responses may thus be interesting.

Abomasal mucosa is often damaged during $H$. contortus infections, which can be due to the presence of the parasite or of reactive oxygen species, which arise during these infections. Tissues can regenerate under improved health conditions, indicated by an increase in mitotic figures in infected tissue. The number of mitotic figures in the abomasal mucosa in our experiment was higher in both MAL and ARTMAL than UNS and ART. Both A. absinthium and M. sy/vestris have strong antioxidant properties, and they may protect abomasal mucosa and promote mucosal healing by the elimination of free radicals.

The thicker mucus in ARTMAL may also have reduced mucosal damage caused by reactive oxygen species because mucus can also act as an antioxidant (50). M. sylvestris alone or in combination with $A$. absinthium may therefore enhance the regeneration of damaged tissue by their antioxidant properties. Dietary supplementation with these two medicinal plants may consequently influence the local immune response in the abomasum and affect the local status of antioxidants of an infected animal, but more research is needed.

\section{Conclusion}

This study represents the first report of the effects of medicinal plants ( $A$. absinthium and $M$. sylvestris) on antioxidant parameters and local immune responses of abomasal mucosa of lambs infected with parasitic GINs. Treatment with the medicinal plants influenced antioxidant parameters in the abomasal mucosa and helped trigger a local immune response in tissues. We can conclude that dietary supplementation with medicinal plants may increase the resistance of lambs to infection with $H$. contortus. Further research, however, is needed to understand these effects of medicinal plants.

\section{Methods}

\section{Animals and experimental design}


All procedures and animal care followed European Community guidelines (EU Directive 2010/63/EU). The experimental protocol was approved by the Ethical Committee of the Institute of Parasitology of the Slovak Academy of Sciences, following national legislation in Slovakia. Permission to collect samples and to carry out the experiment was granted by the participating sheep farmers. The experiment was part of a larger study that evaluated the effect of dry Artemisia absinthium and Malva sylvestris plants on the parasitic gastrointestinal nematode $H$. contortus in lambs, which has previously been described in more detail (31). Briefly, twenty-four 3-4 month-old female lambs (Improved Valachian) with initial body weights of $18.67 \pm 0.55 \mathrm{~kg}$ were housed in common stalls on a commercial sheep farm (Hodkovce, Slovakia) and maintained in their production system during the experiment with free access to water. After a period of adaptation, all parasite-free lambs were infected orally with approximately 5000 thirdstage (L3) larvae of a strain of $H$. contortus (MHCo1) susceptible to anthelmintics (17). Each animal was fed oats (500 g dry matter (DM)/d) and meadow hay (ad libitum). Infected lambs were randomly divided into four groups of six animals each (six lambs/group, one stall/group) based on their live weights: unsupplemented lambs (UNS), lambs supplemented with dried $A$. absinthium stems (ART, $1 \mathrm{~g}$ $\mathrm{DM} / \mathrm{d} / \mathrm{lamb}$ ), lambs supplemented with dried M. sy/vestris flowers (MAL, $15 \mathrm{~g} \mathrm{DM} / \mathrm{d} / \mathrm{lamb}$ ), and lambs supplemented with a mixture of dried $A$. absinthium stems and M. sy/vestris flowers (ARTMAL, $16 \mathrm{~g}$ $\mathrm{DM} / \mathrm{d} / \mathrm{lamb}$ ). The number of animals used in the experiment was assigned following VICH GL13 guidelines proposed by European Medicines Agency. The dried plant components of $A$. absinthium and M. sylvestris both from commercial sources (AGROKARPATY, Plavnica, Slovak Republic) were mixed daily with the oats during the experimental period ( $75 \mathrm{~d})$. Qualitative phytochemical screening of active compounds in aqueous plant extracts (see below) identified mainly tannins and saponins ( $A$. absinthium) and tannins, flavonoids, glycosides, alkaloids, and terpenoids ( $M$. sy/vestris) (31). The phytochemical substances of $A$. absinthium contained $6.48 \mathrm{~g} / \mathrm{kg}$ DM phenolic acids and $0.35 \mathrm{~g} / \mathrm{kg}$ DM flavonoids, $M$. sylvestris contained $0.65 \mathrm{~g} / \mathrm{kg}$ DM phenolic acids and $6.48 \mathrm{~g} / \mathrm{kg}$ DM flavonoids, and the mixture of both plants contained $10.7 \mathrm{~g} / \mathrm{kg}$ DM phenolic acids and $5.51 \mathrm{~g} / \mathrm{kg}$ DM flavonoids (31). The serum samples (on day 75 of infection) were obtained by centrifuging blood samples at $1200 \mathrm{~g}$ for $10 \mathrm{~min}$ at room temperature and were stored at $-70{ }^{\circ} \mathrm{C}$ until analysis. All animals were euthanised by using of pentobarbital overdose (Dolethal, Vetoquinol, UK, Ltd.) on $75 \mathrm{~d}$ after infection, (abattoir of the Centre of Biosciences of SAS, Institute of Animal Physiology, Košice, Slovakia, No. SK U 06018), and helminthological dissections were performed (17). The carcasses were sent at the Department of Pathological Anatomy and Pathological Physiology, University of Veterinary Medicine and Pharmacy in Košice in the Slovak Republic. Mean worm abomasal counts were $899 \pm 95,984 \pm 382,876 \pm 269$ and $787 \pm 335$ for UNS, ART, MAL and ARTMAL, respectively (31). Moreover, samples of their abomasa were collected for the evaluation of antioxidant parameters and histopathological examination.

\section{Plant Methanolic Extracts}

We separately dissolved $0.248 \mathrm{~g}$ of $A$. absinthium and $0.262 \mathrm{~g}$ of $M$. sylvestris in $1 \mathrm{~mL}$ of methanol $(\mathrm{MeOH})$ to final concentrations of $250 \mathrm{mg} / \mathrm{mL}$ and then centrifuged the extracts for separating the insoluble fractions. The supernatants were used for further fractionation. Some fractions were prepared 
using a Dionex Ultimate 3000 semi-preparative high-performance liquid chromatograph (HPLC) with a binary HPLC pump, autosampler, PDA detector, fraction collector (AFC-3000), column-temperature controller, and mobile-phase degasser (Thermo Scientific, Sunnyvale, CA, USA). The fractions were separated on a C18 column $\left(15 \mu \mathrm{m}, 280 \times 10 \mathrm{~mm}\right.$ (Phenomenex, Torrance, CA, USA), tempered at $26^{\circ} \mathrm{C}$ with mobile phases of water $(A)$ and $\mathrm{MeOH}(B)$ by gradient elution. The initial gradient was $5 \%$ phase $B$ (from 0 to $5 \mathrm{~min}$ ), increasing to $100 \% \mathrm{~B}$ in $40 \mathrm{~min}$, which was maintained for $5 \mathrm{~min}$ and was followed by $10 \mathrm{~min}$ of equilibration at an initial level of $5 \% \mathrm{~B}$ from 47 to $57 \mathrm{~min}$. The flow of the mobile phase was $9 \mathrm{~mL} / \mathrm{min}$. An injection volume of the methanolic extract was $100 \mu \mathrm{L}$. The separation was measured as an absorption intensity of spectra monitored within a range of 190-400 nm. The analytical outputs were acquired and processed using Chromeleon 7.2.8 (Thermo Scientific Dionex, Sunnyvale, CA, USA). Some fractions were evaporated to dryness using a vacuum rotary evaporator (Büchi rotavapor 100, Flawil, Switzerland) at $40^{\circ} \mathrm{C}$, redissolved in $1 \mathrm{~mL}$ of $100 \% \mathrm{MeOH}$, moved to 2 -mL vials, and again evaporated to dryness in a stream of nitrogen at $35^{\circ} \mathrm{C}$. The evaporating flask was then washed three times with $1.5 \mathrm{~mL}$ of $\mathrm{MeOH}$, and combined volumes were added to the previous fraction and evaporated using nitrogen. Dry samples were stored at $-18^{\circ} \mathrm{C}$. The compositions and concentrations of the fractions of the methanolic extracts are presented in Table 1.

\section{Calculations And Statistical Analysis}

Data for the antioxidant parameters and immune cells in the abomasal mucosa were evaluated by multiple comparisons using one-way ANOVAs. Differences between the groups in both analyses were evaluated using Bonferroni post hoc tests. Student's $t$-tests were applied to assess the differences between the mean numbers of immune cells for the groups on day 75. The significance level was set at $P$ $<0.05$.

\section{Abbreviations}

ART, lambs supplemented with $A$. absinthium stems; ARTMAL, lambs supplemented with a mixture of $A$. absinthium stems and M. sy/vestris flowers; DM, dry matter; F, fraction; FW, fresh weight; GIN, gastrointestinal nematode; GPx, glutathione peroxidase; HE, haematoxylin and eosin staining; HPLC, highperformance liquid chromatography; MAL, lambs supplemented with $M$. sylvestris flowers; MDA, malondialdehyde; $\mathrm{MeOH}$, methanol; $\mathrm{MHCo} 1, H$. contortus strain susceptible to anthelmintics; NS, not significant; PAS, Periodic acid-Shiff staining; RT, retention time of collection; TAC, total antioxidant capacity; UNS, unsupplemented lambs.

\section{Declarations}

\section{Ethics approval and consent to participate:}

All procedures and animal care followed European Community guidelines (EU Directive 2010/63/EU). The experimental protocol was approved by the Ethical Committee of the Institute of Parasitology of the 
Slovak Academy of Sciences, following national legislation in Slovakia. Permission to collect study samples was granted by the participating sheep farmers. The owners of the animals gave verbal consent to carry out the experiment.

\section{Consent for publication}

Not applicable.

\section{Availability of data and materials}

The datasets used and/or analysed during the current study are available from the corresponding author on reasonable request.

\section{Competing interest}

The authors declare that they have no competing interests.

\section{Funding}

This study was supported by funds from the Slovak Research and Development Agency (APVV 18-0131) and the STSM Grant from the COST Action CA16230 www.combar-ca.eu. The role of the APVV project and STSM Grant of COST project allowed cooperation of researchers and Ph.D. students from the Institute of Animal Physiology of CBv of SAS, Parasitological Institute of SAS, Warsaw University of Life Sciences in Poland, and Czech University of Life Sciences in Prague to address the challenges related to the treatment of parasite infection. The funder had no role in study design, data collection, and analysis, decision to publish, or preparation of the manuscript.

\section{Authors' contributions}

DM performed the laboratory and statistical analyses, interpreted the results, and wrote the manuscript. MSF performed the histopathological analyses and prepared the photographs of the histopathological sections. ZV was responsible for the design of the study, the conception and coordination of the experiment, and reviewed the manuscript. KK performed the antioxidant analyses. $\mathrm{KC}$ reviewed the dossier for the ethical application and critically revised the manuscript. PM and JT analysed the fractions of plant methanolic extracts. JV, MM and JK reviewed the manuscript. MV supervised the research, reviewed the manuscript, and added final corrections. All authors read and approved the final manuscript.

\section{Acknowledgements}

The authors are grateful to Valéria Venglovská, Peter Jerga and Gabriel Benkovský for laboratory and technical assistance. This article is based upon work from COST Action COMBAR CA16230, supported by COST (European Cooperation in Science and Technology).

\section{Authors' information}


${ }^{1}$ Institute of Animal Physiology, Centre of Biosciences of Slovak Academy of Sciences, Košice, Slovak Republic. ${ }^{2}$ Warsaw University of Life Sciences, Faculty of Veterinary Medicine, Department of Pathology and Veterinary Diagnostics, Warsaw, Poland. ${ }^{3}$ Institute of Experimental Botany of the Czech Academy of Sciences, Prague 6 - Lysolaje, Czech Republic. ${ }^{4}$ Czech University of Life Sciences Prague, Faculty of Agrobiology, Food and Natural Resources, Department of Food Science, Prague - Suchdol, Czech Republic. ${ }^{5}$ Czech University of Life Sciences Prague, Faculty of Agrobiology, Food and Natural Resources, Department of Zoology and Fisheries, Prague - Suchdol, Czech Republic. ${ }^{6}$ Warsaw University of Life Sciences, Faculty of Veterinary Medicine, Laboratory of Veterinary Epidemiology and Economics, Warsaw, Poland. ${ }^{7}$ Institute of Parasitology of Slovak Academy of Sciences, Košice, Slovak Republic

\section{References}

1. Besier RB, Kahn LP, Sargison ND, Van Wyk JA. The Pathophysiology, Ecology and Epidemiology of Haemonchus contortus Infection in Small Ruminants. Vol. 93, Advances in Parasitology. Elsevier Ltd; 2016. 95-143 p.

2. Jackson F, Varady M, Bartley DJ. Managing anthelmintic resistance in goats-Can we learn lessons from sheep? Small Rumin Res. 2012;103(1):3-9.

3. Burke JM, Miller JE. Sustainable Approaches to Parasite Control in Ruminant Livestock. Vet Clin North Am - Food Anim Pract. 2020;36(1):89-107.

4. Torres-Acosta JFJ, Hoste H. Alternative or improved methods to limit gastro-intestinal parasitism in grazing sheep and goats. Small Rumin Res. 2008;77(2-3):159-73.

5. Zajičková M, Nguyen LT, Skálová L, Raisová Stuchlíková L, Matoušková P. Anthelmintics in the future: current trends in the discovery and development of new drugs against gastrointestinal nematodes. Drug Discov Today. 2020;25(2):430-7.

6. Githiori JB, Athanasiadou S, Thamsborg SM. Use of plants in novel approaches for control of gastrointestinal helminths in livestock with emphasis on small ruminants. Vet Parasitol. 2006;139(4):308-20.

7. Hoste H, Torres-Acosta JFJ, Quijada J, Chan-Perez I, Dakheel MM, Kommuru DS, et al. Interactions Between Nutrition and Infections With Haemonchus contortus and Related Gastrointestinal Nematodes in Small Ruminants. Vol. 93, Advances in Parasitology. Elsevier Ltd; 2016. 239-351 p.

8. Spiegler V, Liebau E, Hensel A. Medicinal plant extracts and plant-derived polyphenols with anthelmintic activity against intestinal nematodes. Nat Prod Rep. 2017;34(6):627-43.

9. Athanasiadou S, Kyriazakis I. Plant secondary metabolites: antiparasitic effects and their role in ruminant production systems. Proc Nutr Soc. 2004;63(4):631-9.

10. Acamovic T, Brooker JD. Biochemistry of plant secondary metabolites and their effects in animals. Proc Nutr Soc. 2005;64(3):403-12.

11. Wink M. Medicinal plants: A source of anti-parasitic secondary metabolites. Molecules. 2012;17(11):12771-91. 
12. Villalba JJ, Costes-Thiré M, Ginane C. Phytochemicals in animal health: Diet selection and trade-offs between costs and benefits. Proc Nutr Soc. 2017;76(2):113-21.

13. Athanasiadou S, Kyriazakis I, Jackson F, Coop RL. Direct anthelmintic effects of condensed tannins towards different gastrointestinal nematodes of sheep: In vitro and in vivo studies. Vet Parasitol. 2001;99(3):205-19.

14. Hoste H, Martinez-Ortiz-De-Montellano C, Manolaraki F, Brunet S, Ojeda-Robertos N, Fourquaux I, et al. Direct and indirect effects of bioactive tannin-rich tropical and temperate legumes against nematode infections. Vet Parasitol. 2012;186(1-2):18-27.

15. Liu M, Panda SK, Luyten W. Plant-based natural products for the discovery and development of novel anthelmintics against nematodes. Biomolecules. 2020;10(3):426.

16. Váradyová Z, Kišidayová S, Čobanová K, Grešáková, Babják M, Königová A, et al. The impact of a mixture of medicinal herbs on ruminal fermentation, parasitological status and hematological parameters of the lambs experimentally infected with Haemonchus contortus. Small Rumin Res. 2017;151:124-32.

17. Váradyová Z, Mravčáková D, Babják M, Bryszak M, Grešáková L, Čobanová K, et al. Effects of herbal nutraceuticals and/or zinc against Haemonchus contortus in lambs experimentally infected. BMC Vet Res. 2018;14(1).

18. Mravčáková D, Váradyová Z, Kopčáková A, Čobanová K, Grešáková L', Kišidayová S, et al. Natural chemotherapeutic alternatives for controlling of haemonchosis in sheep. BMC Vet Res. 2019;15(1):1-13.

19. Coop RL, Kyriazakis I. Influence of host nutrition on the development and consequences of nematode parasitism in ruminants. Trends Parasitol. 2001;17(7):325-30.

20. Bambou JC, Archimède H, Arquet R, Mahieu M, Alexandre G, González-Garcia E, et al. Effect of dietary supplementation on resistance to experimental infection with Haemonchus contortus in Creole kids. Vet Parasitol. 2011;178(3-4):279-85.

21. Costes-Thiré M, Laurent P, Ginane C, Villalba JJ. Diet selection and trade-offs between condensed tannins and nutrients in parasitized sheep. Vet Parasitol. 2019;271:14-21.

22. Balic A, Bowles VM, Meeusen ENT. Mechanisms of immunity to Haemonchus contortus infection in sheep. Parasite Immunol. 2002;24(1):39-46.

23. Alba-Hurtado F, Muñoz-Guzmán MA. Immune responses associated with resistance to haemonchosis in sheep. Biomed Res Int. 2013;2013(4):162158.

24. Mcrae KM, Stear MJ, Good B, Keane OM. The host immune response to gastrointestinal nematode infection in sheep. Parasite Immunol. 2015;37(12):605-13.

25. Machado V, Da Silva AS, Schafer AS, Aires AR, Tonin AA, Oliveira CB, et al. Relationship between oxidative stress and pathological findings in abomasum of infected lambs by Haemonchus contortus. Pathol Res Pract. 2014;210(12):812-7.

26. Gessner DK, Ringseis R, Eder K. Potential of plant polyphenols to combat oxidative stress and inflammatory processes in farm animals. J Anim Physiol Anim Nutr. 2017;101(4):605-28. 
27. Poli CHEC, Thornton-Kurth KJ, Legako JF, Bremm C, Hampel VS, Hall J, et al. Self-selection of plant bioactive compounds by sheep in response to challenge infection with Haemonchus contortus. Physiol Behav. 2018;194:302-10.

28. Balic A, Bowles VM, Meeusen ENT. Cellular profiles in the abomasal mucosa and lymph node during primary infection with Haemonchus contortus in sheep. Vet Immunol Immunopathol. 2000;75(12):109-20.

29. Amarante AFT, Bricarello PA, Huntley JF, Mazzolin LP, Gomes JC. Relationship of abomasal histology and parasite-specific immunoglobulin $A$ with the resistance to Haemonchus contortus infection in three breeds of sheep. Vet Parasitol. 2005;128(1-2):99-107.

30. Muñoz-Guzmán MA, Cuenca-Verde C, Valdivia-Anda G, Cuéllar-Ordaz JA, Alba-Hurtado F. Differential immune response between fundic and pyloric abomasal regions upon experimental ovine infection with Haemonchus contortus. Vet Parasitol. 2012;185(2-4):175-80.

31. Mravčáková $D$, Komáromyová $M$, Babják $M$, Dolinská $M U$, Königová $A$, Petrič $D$, et al. Anthelmintic activity of wormwood (Artemisia absinthium L.) and mallow (Malva sylvestris L.) against Haemonchus contortus in sheep. Animals. 2020;10(2):1-15.

32. Barros $L$, Carvalho AM, Ferreira ICFR. Leaves, flowers, immature fruits and leafy flowered stems of Malva sylvestris: A comparative study of the nutraceutical potential and composition. Food Chem Toxicol. 2010;48(6):1466-72.

33. El G, Batiha S, Olatunde A, Mleeh A, El, Hetta HF, Rejaie S, Al, et al. Bioactive Compounds, Pharmacological Actions, and Pharmacokinetics of Wormwood (Artemisia absinthium). 2020;9(6):353.

34. Do Reo Leal ML, De Camargo EV, Henrique Ross D, Molento MB, Dos Anjos Lopes ST, Da Rocha JBT. Effect of selenium and vitamin $E$ on oxidative stress in lambs experimentally infected with Haemonchus contortus. Vet Res Commun. 2010;34(6):549-55.

35. Kaurinovic B, Vastag D. Flavonoids and Phenolic Acids as Potential Natural Antioxidants. Antioxidants. 2019.

36. Celi P. The role of oxidative stress in small ruminants' health and production. Rev Bras Zootec. 2010;39:348-63.

37. Bora KS, Sharma A. Evaluation of antioxidant and free-radical scavenging potential of Artemisia absinthium. Pharm Biol. 2011;49(12):1216-23.

38. Paolini V, Bergeaud JP, Grisez C, Prevot F, Dorchies P, Hoste H. Effects of condensed tannins on goats experimentally infected with Haemonchus contortus. Vet Parasitol. 2003;113(3-4):253-61.

39. Pérez J, Garcia PM, Hernandez S, Martinez-Moreno A, Martin De Las Mulas J, Camara S. Pathological and immunohistochemical study of the abomasum and abomasal lymph nodes in goats experimentally infected with Haemonchus contortus. Vet Res. 2001;32(5):463-73.

40. Venturina VM, Gossner AG, Hopkins J. The immunology and genetics of resistance of sheep to Teladorsagia circumcincta. Vet Res Commun. 2013;37(2):171-81. 
41. Salman SK, Duncan JL. The abomasal histology of worm-free sheep given primary and challenge infections of Haemonchus contortus. Vol. 16, Veterinary Parasitology. 1984. p. 43-54.

42. Grencis RK, Humphreys NE, Bancroft AJ. Immunity to gastrointestinal nematodes: Mechanisms and myths. Immunol Rev. 2014;260(1):183-205.

43. Balic A, Cunningham CP, Meeusen ENT. Eosinophil interactions with Haemonchus contortus larvae in the ovine gastrointestinal tract. Parasite Immunol. 2006;28(3):107-15.

44. Balic A, Bowles VM, Meeusen ENT, Bowles M. The immunobiology of gastrointestinal nematode infections in ruminants. Adv Parasitol. 2000;45:181-241.

45. Terefe G, Lacroux C, Andreoletti O, Grisez C, Prevot F, Bergeaud JP, et al. Immune response to Haemonchus contortus infection in susceptible (INRA 401) and resistant (Barbados Black Belly) breeds of lambs. Parasite Immunol. 2007;29(8):415-24.

46. Krystel-Whittemore M, Dileepan KN, Wood JG. Mast cell: A multi-functional master cell. Front Immunol. 2016;6:1-12.

47. Galli SJ, Nakae S, Tsai M. Mast cells in the development of adaptive immune responses. Nat Immunol. 2005;6(2):135-42.

48. Tzamaloukas O, Athanasiadou S, Kyriazakis I, Huntley JF, Jackson F. The effect of chicory (Cichorium intybus) and sulla (Hedysarum coronarium) on larval development and mucosal cell responses of growing lambs challenged with Teladorsagia circumcincta. Parasitology. 2006;132(3):419-26.

49. Robinson N, Piedrafita D, Snibson K, Harrison P, Meeusen EN. Immune cell kinetics in the ovine abomasal mucosa following hyperimmunization and challenge with Haemonchus contortus. Vet Res. 2010;41(4):37.

50. Penissi AB, Piezzi RS. Effect of dehydroleucodine on mucus production: A quantitative study. Dig Dis Sci. 1999;44(4):708-12.

51. Čobanová K, Chrastinová, Chrenková M, Polačiková M, Formelová Z, Ivanišinová O, et al. The effect of different dietary zinc sources on mineral deposition and antioxidant indices in rabbit tissues. World Rabbit Sci. 2018;26(3):241-8.

52. Paglia DE, Valentine WN. Studies on the quantitative and qualitative characterization of erythrocyte glutathione peroxidase. J Lab Clin Med. 1967;70(1):158-69.

53. Benzie IFF, Strain JJ. Ferric reducing/antioxidant power assay: Direct measure of total antioxidant activity of biological fluids and modified version for stimultaneous measurement of total antioxidant power and ascorbic acid concentration. Methods Enzymol. 1999;299:15-27.

54. Jo C, Ahn DU. Fluorometric Analysis of 2-Thiobarbituric Acid Reactive Substances in Turkey. Poult Sci. 1998;77(3):475-80.

55. Bradford MM. A rapid and sensitive method for the quantitation of microgram quantities of protein utiliing the principle of protein-dye binding. Anal Biochem. 1976;72:248-54. 


\section{Figures}

A

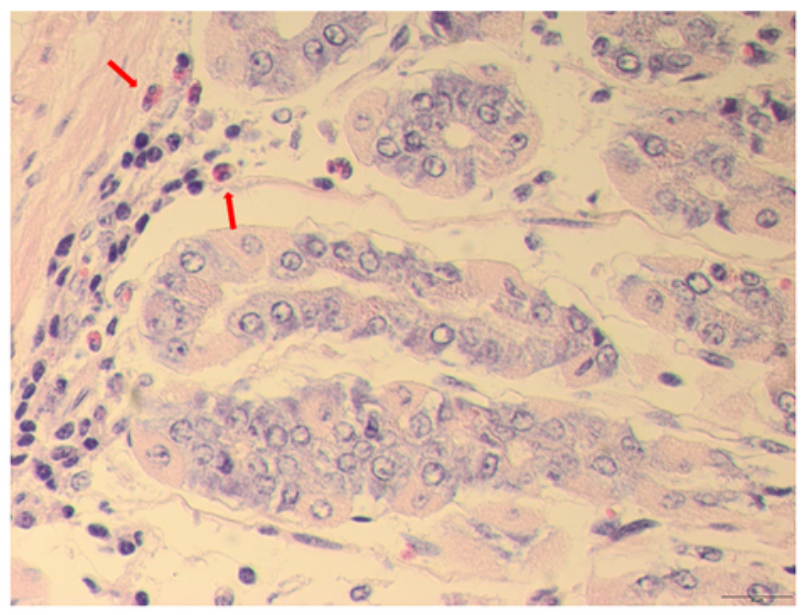

C

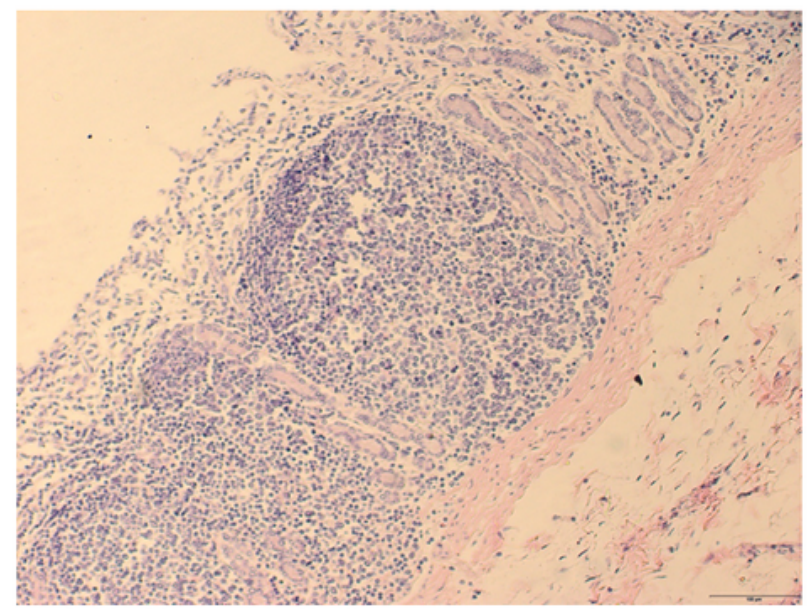

E

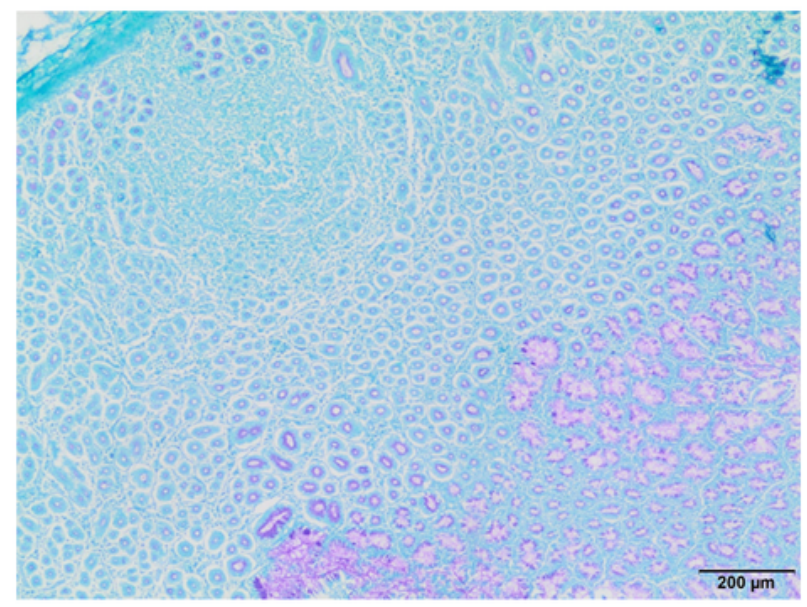

B

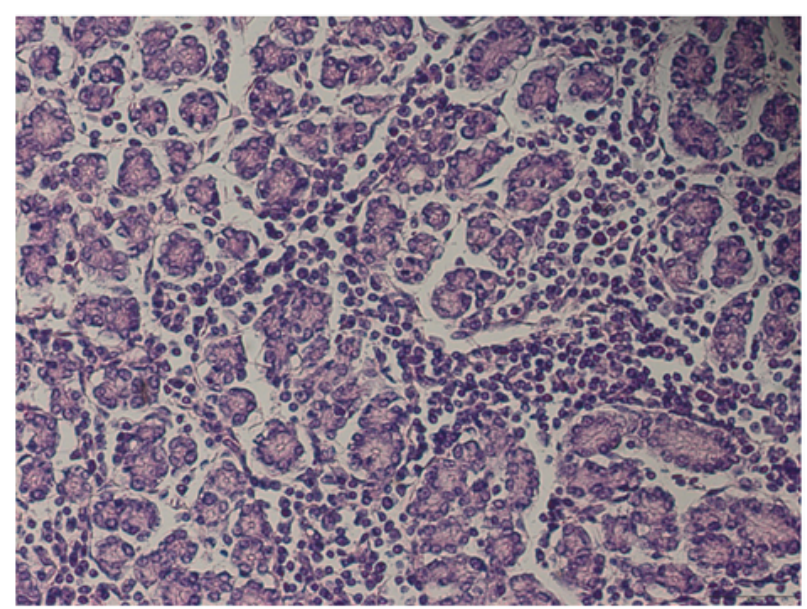

D

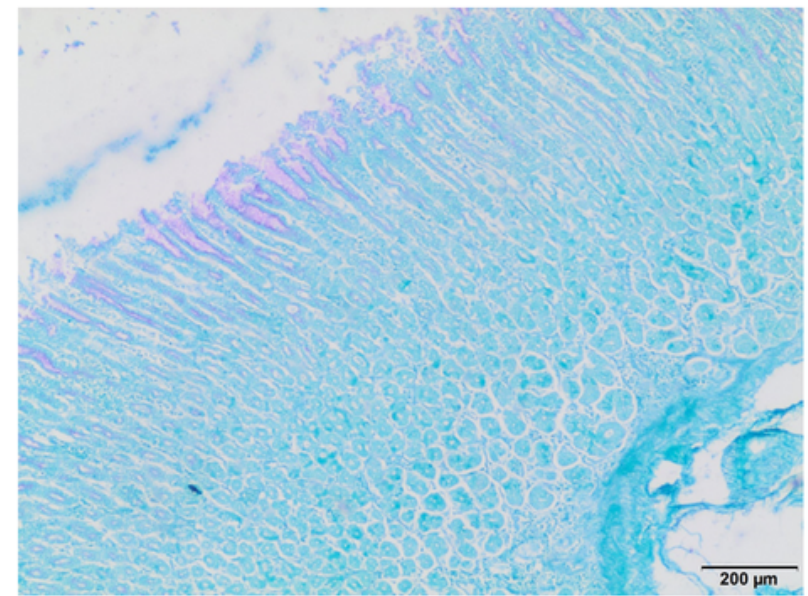

\section{F}

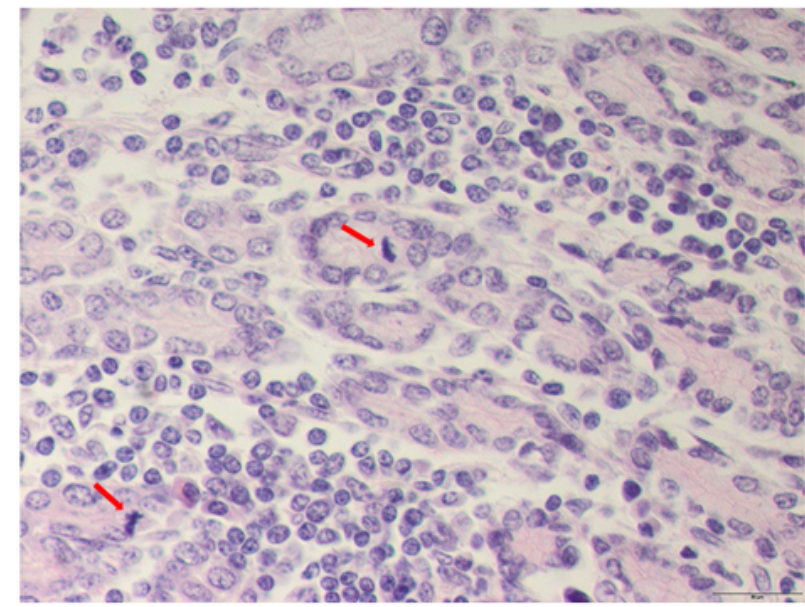

\section{Figure 1}

Histopathological sections of sheep abomasa infected with Haemonchus contortus. A, Section stained by haematoxylin and eosin (HE) (400x) showing infiltration with eosinophils in unsupplemented lambs (UNS). B, Section stained by HE (200x) showing strong inflammation in the mucosal membranes in 
lambs supplemented with a mixture of $A$. absinthium stems and $M$. sylvestris flowers (ARTMAL). C, Section stained by HE (100x) showing formation of lymphoid nodules in the mucous membrane in lambs supplemented with M. sylvestris flowers (MAL). D, Section stained by Periodic acid-Shiff (PAS) (40x) showing mucus formation in the superficial part of the mucosal membrane in UNS. E, Section stained by PAS (40x) showing mucus formation in all layers of the mucosal membrane and distention of superficial parts of glands in lambs supplemented with A. absinthium stems (ART). F, Section stained by HE (200x) showing moderate mitotic activity of the epithelial cells and inflammatory infiltrate with mononuclear cells in ART.

A

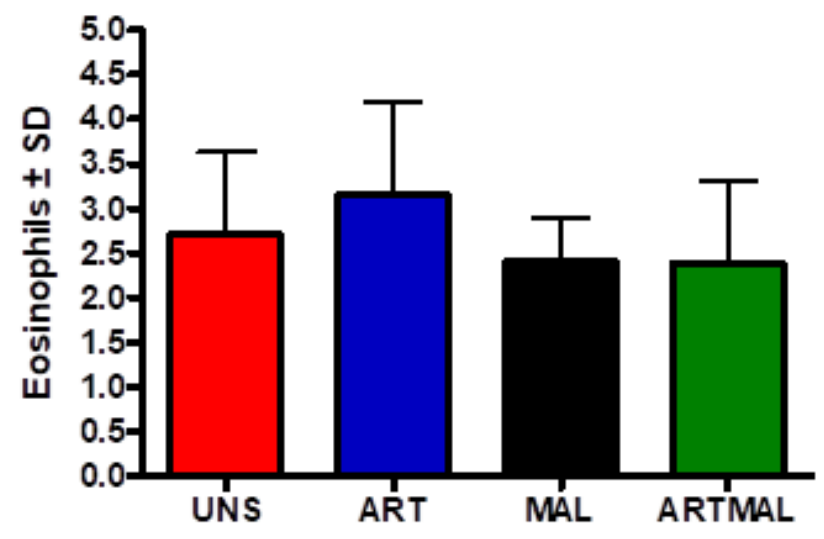

C

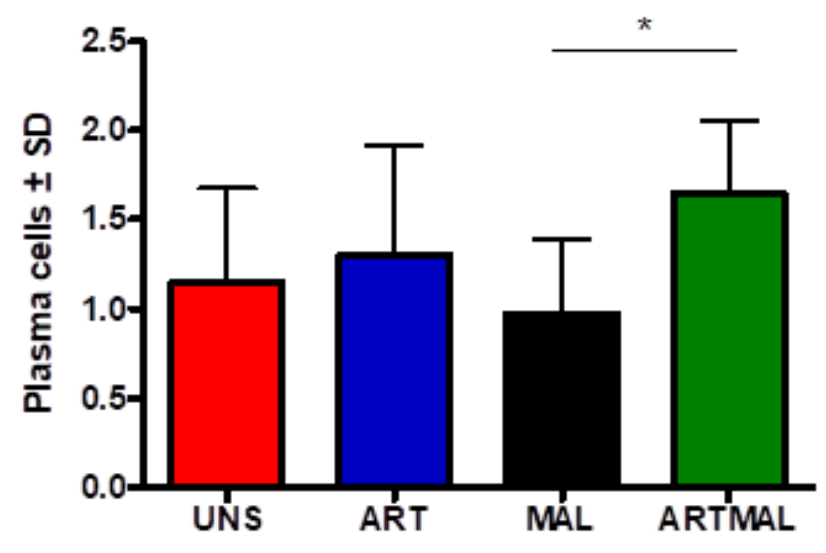

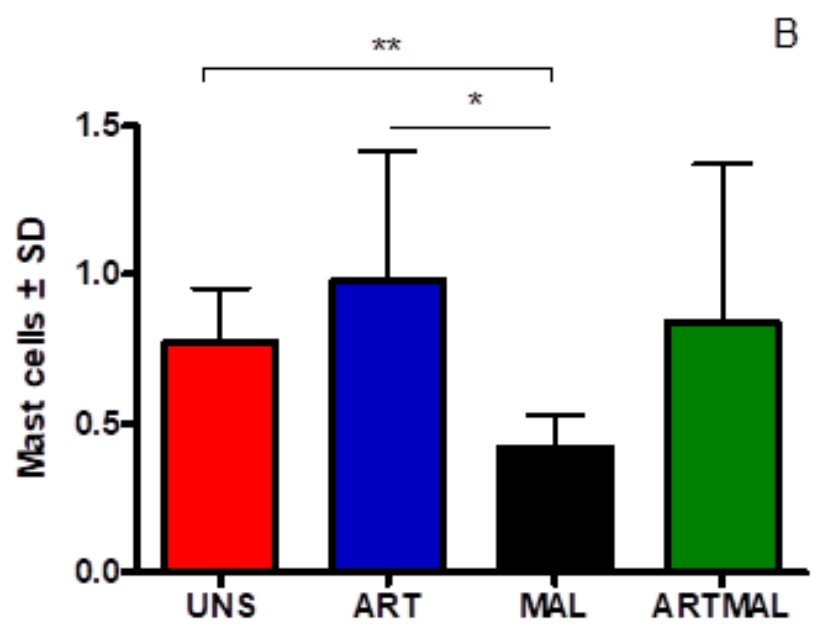

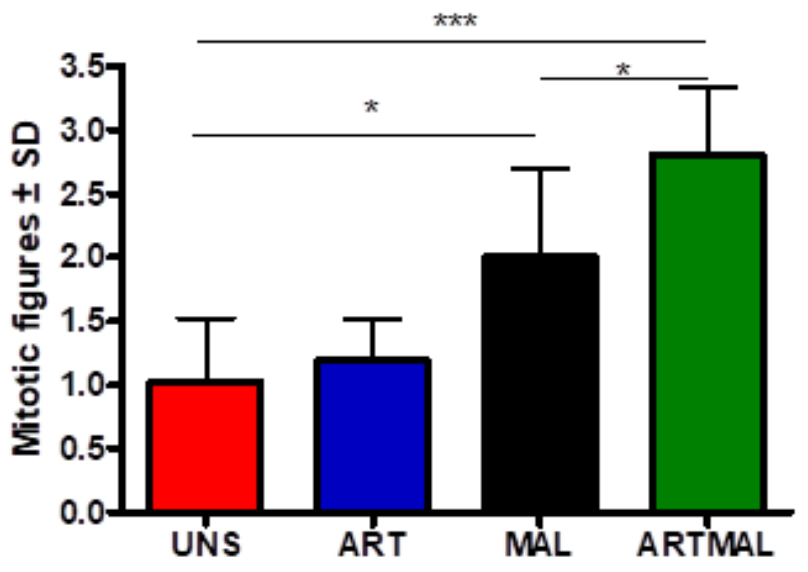

Figure 2

Mean numbers of different immune cells and mitotic figures in the abomasa of lambs infected with Haemonchus contortus fed with different diets ( ${ }^{\star}, \mathrm{P}<0.05$; $\left.* \star \star, P<0.001\right)$. UNS, unsupplemented lambs; ART, lambs supplemented with A. absinthium stems; MAL, lambs supplemented with M. sylvestris flowers; ARTMAL, lambs supplemented with a mixture of $A$. absinthium stems and M. sylvestris flowers.

\section{Supplementary Files}


This is a list of supplementary files associated with this preprint. Click to download.

- AuthorChecklistFull.pdf 